\title{
KEMAMPUAN PEMECAHAN MASALAH MATEMATIKA DITINJAU BERDASARKAN DEKOMPOSISI GENETIK PADA SISWA KELAS VIII SMPN 2 PONDOK KELAPA KABUPATEN BENGKULU TENGAH
}

\author{
Azhari. MR ${ }^{1}$ Wahyu Widada dan M. Ilham Abdullah ${ }^{2}$ \\ ${ }^{1}$ Mahasiswa dan ${ }^{2}$ Dosen Program Studi Pascasarjana (S2) Pendidikan \\ Matematika FKIP UNIB \\ E-mail: azharimr29@gmail.com
}

\begin{abstract}
ABSTRAK
Penelitian ini bertujuan untuk menganalisis kemampuan pemecahan masalah matematika dan peta kemampuan yang terbentuk berdasarkan dekomposisi genetik pada siswa Kelas VIII SMPN 2 Pondok Kelapa Kabupaten Bengkulu Tengah. Subyek dalam penelitian ini adalah seluruh siswa Kelas VIII SMPN 2 Pondok Kelapa Kabupaten Bengkulu Tengah. Metode pengumpulan data menggunakan tes diagnostik dan wawancara terstruktur. Metode analisis menggunakan Metode Deskriptif Kualitatif. Hasil penelitian menunjukkan bahwa (1) kemampuan pemecahan masalah matematika berdasarkan dekomposisi genetic dengan Level Triad pada siswa Kelas VIII SMPN 2 Pondok Kelapa Kabupaten Bengkulu Tengah menunjukkan bahwa termasuk kategori kurang (Level Intra) sebanyak 39 orang (65\%) yang merupakan jumlah terbanyak, kategori cukup (Level Inter) sebanyak 9 orang (15\%) yang merupakan jumlah paling sedikit dan kategori baik (Level Trans) sebanyak 12 orang (20\%). Secara keseluruhan, kemampuan pemahaman masalah matematika berdasarkan dekomposisi genetik dengan Level Triad siswa Kelas VIII di sekolah tersebut termasuk kategori kurang (Level Intra) dan (2) peta kemampuan pemecahan masalah matematika berdasarkan dekomposisi genetik pada siswa Kelas VIII SMPN 2 Pondok Kelapa Kabupaten Bengkulu Tengah menunjukkan bahwa sebanyak 24 siswa (40\%) dengan kinerja konstruksi mental Aksi, Proses, Skema dan Obyek yang baik dan 36 siswa (60\%) dengan kinerja konstruksi mental Aksi, Proses, Skema dan Obyek yang buruk.
\end{abstract}

Kata kunci: dekomposisi genetik; masalah matematika; pemecahan masalah; pemecahan masalah matematika.

\begin{abstract}
The purposes of research are to analyze the solving ability of problems based on genetic decomposition and the map of it on the second grade students of Junior Public School 2 of Pondok Kelapa, Middle Bengkulu Regency. Subjects in this research are all of the second grade students of Public Junior High School 2 of Pondok Kelapa, Middle Bengkulu Regency. Method of collecting data uses diagnostic test and structured interview. Method of data analysis uses qualitative descriptive method. Results of the research shows that (1) the solving ability of mathematics problems based on genetic decomposition with Triad Level on the second grade students of Public Junior High 2 of Pondok Kelapa, Middle Bengkulu Regency amounts of 39 students (65\%) are in less category (Intra Level) as the greatest number, 9 students (15\%) are in enough category (Inter Level) as the least number and 12 students (20\%) are in good category (Trans Level). Totally, the solving ability of mathematics problems based on genetic decomposition with Triad Level on the second grade students of that school are in less category (Intra Level) and (2) map of the solving ability of mathematics problems based on genetic decomposition on the second grade students of Public Junior High 2 of Pondok Kelapa, Middle Bengkulu Regency amounts of 24 students (40\%) are in good performance for mental construction Action, Process, Scheme and Object and 36 students (60\%) are in bad performance for them.
\end{abstract}

Keywords: genetic decomposition; mathematics problems; mathematics problems solving; problems solving. 


\section{PENDAHULUAN}

Pemecahan masalah adalah suatu usaha untuk mencari jalan keluar dari suatu kesulitan ataupun mencari suatu tujuan yang tidak dengan segera dapat dicapai. Pemecahan masalah merupakan suatu tingkat aktivitas intelektual yang tinggi (Polya dalam Hudojo, 2009: 87). Kemampuan pemecahan masalah adalah kesanggupan atau kecakapan seseorang dalam mencari jalan keluar dari suatu permasalahan untuk memperoleh pengetahuan dan pemahaman konsep berpikir tingkat tinggi secara ilmiah.

Berdasarkan survei awal yang dilakukan di Sekolah Menengah Pertama Negeri (SMPN) 2 Pondok Kelapa, Kabupaten Bengkulu Tengah menunjukkan bahwa banyak siswa Kelas VIII yang mengalami kesulitan dalam mengerjakan ataupun menyelesaikan masalah matematika. Jawaban siswa banyak yang sama dan hanya mengikuti cara (metode) penyelesaian yang diberikan oleh guru. Tidak ada jawaban yang bervariasi yang mampu menggambarkan kemampuan pemecahan masalah matematika siswa sesungguhnya.

Masalah matematika adalah pertanyaan (soal) matematika non-rutin yang mencakup aplikasi prosedur matematika. Untuk sampai pada prosedur yang benar diperlukan pemikiran yang lebih mendalam dimana soal tersebut cukup kompleks, sehingga siswa tidak mengetahui gambaran tentang jawaban soal itu, namun berkeinginan untuk menyelesaikannya (Foong dalam Warsita, 2009: 12). Pemecahan masalah matematika dapat diartikan sebagai usaha siswa untuk menyelesaikan suatu pertanyaan (soal) tanpa menggunakan prosedur rutin berdasarkan pengetahuan, keterampilan dan pemahaman yang dimiliki siswa (Shadiq, 2005: 46). Artinya, dalam memecahkan masalah matematika perlu diperhatikan jawaban yang diperoleh, aturan dan konsep yang digunakan.

Menurut Krulik \& Rays (dalam Shadiq, 2005: 39), pentingnya kemampuan pemecahan masalah dalam pembelajaran matematika, yaitu (1) kemampuan pemecahan masalah merupakan tujuan utama pembelajaran matematika, (2) pemecahan masalah dapat meliputi metode, prosedur, strategi atau cara yang digunakan yang merupakan proses inti (utama) dalam kurikulum matematika, (3) pemecahan masalah merupakan kemampuan dasar dalam belajar matematika. Kemampuan pemecahan masalah dalam matematika merupakan hal yang sangat 
penting untuk dimiliki siswa dan juga merupakan salah satu faktor yang menentukan hasil belajar siswa untuk setiap pokok bahasan (bab).

Salah satu pokok bahasan dalam pembelajaran matematika yang diajarkan kepada siswa kelas VIII Sekolah Menengah Pertama (SMP) adalah pokok bahasan Sistem Persamaan Linear Dua Variabel (SPLDV). Seperti pokok bahasan lainnya, pokok bahasan ini juga memiliki materi prasyarat yang terlebih dahulu harus dikuasai oleh siswa agar materi ini dapat dipahami dengan baik dan sesuai dengan indikator yang telah ditetapkan, baik berupa Standar Kompetensi (SK) dan Kompetensi Dasar (KD).

Materi prasyarat yang dibutuhkan untuk memahami SPLDV meliputi (1) Sistem Persamaan Linier Satu Variabel (SPLSV) untuk tahapan akhir dalam menentukan nilai $x$ atau $y$ (penyelesaian akhir dari Metode Eliminasi dan Subsitusi); (2) aljabar untuk menentukan operasi penjumlahan, pengurangan, perkalian, pembagian aljabar dan suku-suku sejenis; (3) aritmatika sosial untuk menentukan jawaban dari soal-soal SPLDV dalam bentuk cerita (uraian); (4) Sistem Koordinat Cartesius untuk menentukan jawaban dari soal-soal SPLDV dengan Metode Grafik, dan (5) Persamaan Garis Lurus (SPL) yang mendukung pemahaman siswa terhadap skema aljabar. Melalui kelima materi prasyarat dalam SPLDV ini, maka siswa dapat menemukan jawaban dari berbagai masalah matematika.

Dengan tingkat pemahaman siswa yang berbeda dari kelima materi prasyarat untuk dapat memahami materi SPLDV, maka akan dapat diketahui gambaran kemampuan siswa dalam pemecahan masalah matematika. Kemampuan tersebut akan ditinjau berdasarkan dekomposisi genetik. Menurut Wahyu (2005: 29), “dekomposisi genetik (model kognisi) adalah suatu kumpulan terstruktur dari aktivitas mental yang membangun blok (kategori-kategori) untuk mendeskripsikan bagaimana konsep/prinsip dapat dikembangkan dalam pikiran seorang individu". Konstruksi mental tersebut adalah aksi, proses, obyek dan skema yang merupakan kerangka kerja teoritis dari Teori Action, Process, Object and Scheme (APOS) atau Teori Aksi, Proses, Obyek dan Skema.

Berdasarkan uraian latar belakang di atas, yang menjadi rumusan masalah dalam penelitian ini adalah, (1) bagaimana kemampuan pemecahan masalah 
matematika berdasarkan dekomposisi genetik pada siswa Kelas VIII SMPN 2 Pondok Kelapa Kabupaten Bengkulu Tengah? dan (2) bagaimana peta kemampuan pemecahan masalah matematika berdasarkan dekomposisi genetik pada siswa Kelas VIII SMPN 2 Pondok Kelapa Kabupaten Bengkulu Tengah?. Tujuan yang dicapai dari penelitian, yaitu (1) menganalisis kemampuan pemecahan masalah matematika berdasarkan dekomposisi genetik pada siswa Kelas VIII SMPN 2 Pondok Kelapa Kabupaten Bengkulu Tengah dan (2) peta pemecahan masalah matematika berdasarkan dekomposisi genetik pada siswa Kelas VIII di sekolah tersebut.

\section{METODE PENELITIAN}

Jenis penelitian ini bersifat deskriptif kualitatif. Subyek dalam penelitian ini adalah seluruh siswa Kelas VIII SMPN 2 Pondok Kelapa, Kabupaten Bengkulu Tengah. Jumlah subyek ditentukan dengan menggunakan data sekunder yang dimiliki oleh sekolah tersebut. Jumlah seluruh siswa Kelas VIII di sekolah tersebut sebanyak 60 orang. Penentuan responden penelitian menggunakan metode total sampling, sehingga jumlah seluruh responden dalam penelitian ini sebanyak 60 orang.

Instrumen utama dalam penelitian ini adalah peneliti sendiri. Peneliti merupakan perencana, pelaksana pengumpulan data, penganalisis, penafsir data sekaligus pelapor hasil penelitian. Instrumen tambahan yang digunakan berupa lembar tes diagnostik yang berisikan 8 soal uraian yang disajikan dalam bentuk cerita dan gambar.

Prosedur Penelitian sebagai berikut: 1) Pendahuluan Pada tahapan ini, guru menyampaikan materi mengenai pokok bahasan Sistem Persamaan Linier Dua Variabel (SPLDV) dengan disertai beberapa contoh dan soal untuk menambah pemahaman siswa terhadap materi tersebut; 2) Kegiatan Inti dalam penelitian ini dengan melibatkan konstruksi mental dari dekomposisi genetik, yaitu teori APOS yang terdiri atas Aksi, Proses, Obyek dan Skema; 3) Penutup, kegiatan yang dilakukan pada tahapan penutup sebagai berikut: guru mengingatkan kembali mengenai konsep-konsep inti dari materi SPLDV sebagai bentuk kesimpulan 
pembelajaran dan guru memberikan masalah matematika lainnya untuk dikerjakan di rumah untuk menambah pemahaman siswa mengenai materi SPLDV.

Teknik pengumpulan data dalam penelitian ini sebagai berikut: yang pertama adalah Tes diagnostik (tertulis). Tes diagnostik bertujuan untuk mengetahui gambaran kemampuan pemecahan masalah matematika berdasarkan dekomposisi genetik responden secara tertulis. Kategori kemampuan pemahaman siswa terhadap masalah matematika berdasarkan aspek proses dan metode yang digunakan dapat dilihat pada Tabel 3.2.

Tabel 3.2. Kategori Kemampuan Pemahaman Masalah Matematika Siswa Berdasarkan Aspek Proses dan Metode

\begin{tabular}{|c|c|c|}
\hline \multirow{2}{*}{ Kesesuaian dengan Pembahasan } & \multicolumn{2}{|c|}{ Kategori Kemampuan Pemahaman } \\
\cline { 2 - 3 } & Secara Umum & Dekomposisi Genetik \\
\hline Sesuai & Baik & Level Trans \\
\hline Kurang Sesuai & Cukup & Level Inter \\
\hline Tidak Sesuai & Kurang & Level Intra \\
\hline
\end{tabular}

Sumber: Suherman, 2009: 88; Wahyu, 2005: 53 dan Wahyu, 2015: 2

Kategori kemampuan pemahaman siswa terhadap masalah matematika berdasarkan aspek hasil yang digunakan dapat dilihat pada Tabel 3.3.

Tabel 3.3. Kategori Kemampuan Pemahaman Masalah Matematika Siswa Berdasarkan Aspek Hasil

\begin{tabular}{|c|c|c|}
\hline \multirow{2}{*}{ Skor (Skala 100) } & \multicolumn{2}{|c|}{ Kategori Kemampuan Pemahaman } \\
\cline { 2 - 3 } & Secara Umum & Dekomposisi Genetik \\
\hline$\geq 71$ & Baik & Level Trans \\
\hline $56 \leq$ Skor $\leq 70$ & Cukup & Level Inter \\
\hline$\leq 55$ & Kurang & Level Intra \\
\hline
\end{tabular}

Sumber: Wahyu, 2005: 53; Wahyu, 2011: 3 dan Wahyu, 2015: 2

Kedua adalah Wawancara terstruktur. Wawancara terstruktur bertujuan untuk melengkapi data mengenai gambaran peta pemecahan masalah matematika berdasarkan dekomposisi genetik responden penelitian. Untuk memperoleh data yang akurat dan valid, peneliti melaksanakan tahapan wawancara terstruktur dengan menggunakan lembar panduan wawancara yang telah dipersiapkan terlebih dahulu. Tujuannya agar peneliti mampu mendeksripsikan gambaran peta 
kemampuan pemecahan masalah matematika berdasarkan dekomposisi genetik responden secara lebih sistematis, fokus dan terarah.

Teknik Analisis Data yang dipakai adalah sebagai berikut: 1) Pengumpulan data sekaligus reduksi data (collecting and reduction data); 2) Penyajian data (display data) 3) Triangulasi (triangulation); dan 3) Penarikan kesimpulan (verification)

\section{HASIL PENELITIAN DAN PEMBAHASAN}

Gambaran kemampuan pemecahan masalah matematika dan peta kemampuan tersebut ditinjau berdasarkan dekomposisi genetik pada siswa Kelas VIII SMPN 2 Pondok Kelapa, Kabupaten Bengkulu Tengah.

\section{Kemampuan Pemecahan Masalah Matematika Berdasarkan Dekomposisi}

Genetik pada Siswa Kelas VIII SMPN 2 Pondok Kelapa Kabupaten

\section{Bengkulu Tengah}

Rekapitulasi data hasil tes diagnostik dari kedua kelas tersebut berdasarkan aspek proses dan metode yang digunakan serta hasil yang dicapai dapat dilihat pada Tabel 1, Gambar 1, Tabel 2 dan Gambar 2.

Tabel 1. Data Hasil Tes Diagnostik Siswa Kelas VIII.A SMPN 2 Pondok Kelapa, Kabupaten Bengkulu Tengah

\begin{tabular}{|c|c|c|c|c|c|c|}
\hline \multirow{2}{*}{ No } & Inisial & $\begin{array}{c}\text { Proses dan } \\
\text { Metode }\end{array}$ & $\begin{array}{c}\text { Jumlah } \\
\text { Jawaban } \\
\text { Benar }\end{array}$ & Skor & & \multicolumn{2}{|l|}{ Kategori Kemampuan Pemahaman } \\
\cline { 5 - 7 } & & & Umum & Dekomposisi Genetik \\
\hline \hline 1 & AK & Tidak Sesuai & 2 & 25 & Kurang & Level Intra \\
\hline 2 & AP & Tidak Sesuai & 3 & 37,5 & Kurang & Level Intra \\
\hline 3 & BD & Tidak Sesuai & 2 & 25 & Kurang & Level Intra \\
\hline 4 & BH & Sesuai & 6 & 75 & Baik & Level Trans \\
\hline 5 & BL & Tidak Sesuai & 4 & 50 & Kurang & Level Intra \\
\hline 6 & CB & Tidak Sesuai & 4 & 50 & Kurang & Level Intra \\
\hline 7 & DA & Sesuai & 6 & 75 & Baik & Level Trans \\
\hline 8 & DD & Tidak Sesuai & 4 & 50 & Kurang & Level Intra \\
\hline 9 & DS & Tidak Sesuai & 4 & 50 & Kurang & Level Intra \\
\hline 10 & EA & Sesuai & 6 & 75 & Baik & Level Trans \\
\hline 11 & EJ & Sesuai & 5 & 62,5 & Cukup & Level Inter \\
\hline 12 & EK & Tidak Sesuai & 3 & 37,5 & Kurang & Level Intra \\
\hline 13 & FA & Tidak Sesuai & 3 & 37,5 & Kurang & Level Intra \\
\hline 14 & FP & Tidak Sesuai & 4 & 50 & Kurang & Level Intra \\
\hline 15 & FR & Kurang Sesuai & 5 & 62,5 & Cukup & Level Inter \\
\hline 16 & HA & Sesuai & 8 & 100 & Baik & Level Trans \\
\hline
\end{tabular}



SMPN 2 Pondok Kelapa Kabupaten Bengkulu Tengah

\begin{tabular}{|c|c|c|c|c|c|c|}
\hline \multirow{2}{*}{ No } & Inisial & $\begin{array}{c}\text { Proses dan } \\
\text { Metode }\end{array}$ & $\begin{array}{c}\text { Jumlah } \\
\text { Jawaban } \\
\text { Benar }\end{array}$ & Skor & \multicolumn{2}{|c|}{ Kategori Kemampuan Pemahaman } \\
17 & HD & Sesuai & 5 & 62,5 & Cukup & Dekomposisi Genetik \\
\hline 18 & HH & Tidak Sesuai & 3 & 37,5 & Kurang & Level Inter \\
\hline 19 & JA & Kurang Sesuai & 5 & 62,5 & Cukup & Level Inter \\
\hline 20 & JL & Sesuai & 7 & 87,5 & Baik & Level Trans \\
\hline 21 & JS & Tidak Sesuai & 4 & 50 & Kurang & Level Intra \\
\hline 22 & LM & Sesuai & 5 & 62,5 & Cukup & Level Inter \\
\hline 23 & MD & Tidak Sesuai & 3 & 37,5 & Kurang & Level Intra \\
\hline 24 & MY & Tidak Sesuai & 3 & 37,5 & Kurang & Level Intra \\
\hline 25 & PJ & Tidak Sesuai & 4 & 50 & Kurang & Level Intra \\
\hline 26 & RA & Tidak Sesuai & 2 & 25 & Kurang & Level Intra \\
\hline 27 & RF & Tidak Sesuai & 3 & 37,5 & Kurang & Level Intra \\
\hline 28 & RP & Tidak Sesuai & 4 & 50 & Kurang & Level Intra \\
\hline 29 & YS & Tidak Sesuai & 2 & 25 & Kurang & Level Intra \\
\hline 30 & ZF & Sesuai & 6 & 75 & Baik & Level Trans \\
\hline \hline
\end{tabular}

Sumber: Data Primer, 2016

Tabel 4.1 menunjukkan kemampuan pemahaman masalah matematika ditinjau berdasarkan dekomposisi genetik dengan Level Triad pada siswa Kelas VIII.A SMPN 2 Pondok Kelapa, Kabupaten Bengkulu Tengah dengan kategori kurang (Level Intra) sebanyak 19 orang $(63,33 \%)$ yang merupakan jumlah terbanyak, kategori cukup (Level Inter) sebanyak 5 orang $(16,67 \%$ ) yang merupakan jumlah paling sedikit dan kategori baik (Level Trans) sebanyak 6 orang (20\%). Namun, berdasarkan proses dan metode yang digunakan, terdapat 2 orang (40\%) dari kelompok siswa kategori cukup (Level Inter) dengan jawaban yang kurang sesuai dengan pembahasan yang diberikan.

Secara keseluruhan, kemampuan pemahaman masalah matematika siswa Kelas VIII.A di sekolah ini berdasarkan dekomposisi genetik dengan Level Triad termasuk kategori kurang (Level Intra) dengan rata-rata skor 52,08 dan rata-rata jumlah jawaban benar 4 soal (pembulatan) atau setengah (50\%) dari jumlah pertanyaan yang diberikan.

Histogram kemampuan pemahaman masalah matematika berdasarkan dekomposisi genetik dengan Level Triad siswa Kelas VIII.A dapat dilihat pada Gambar 1. 


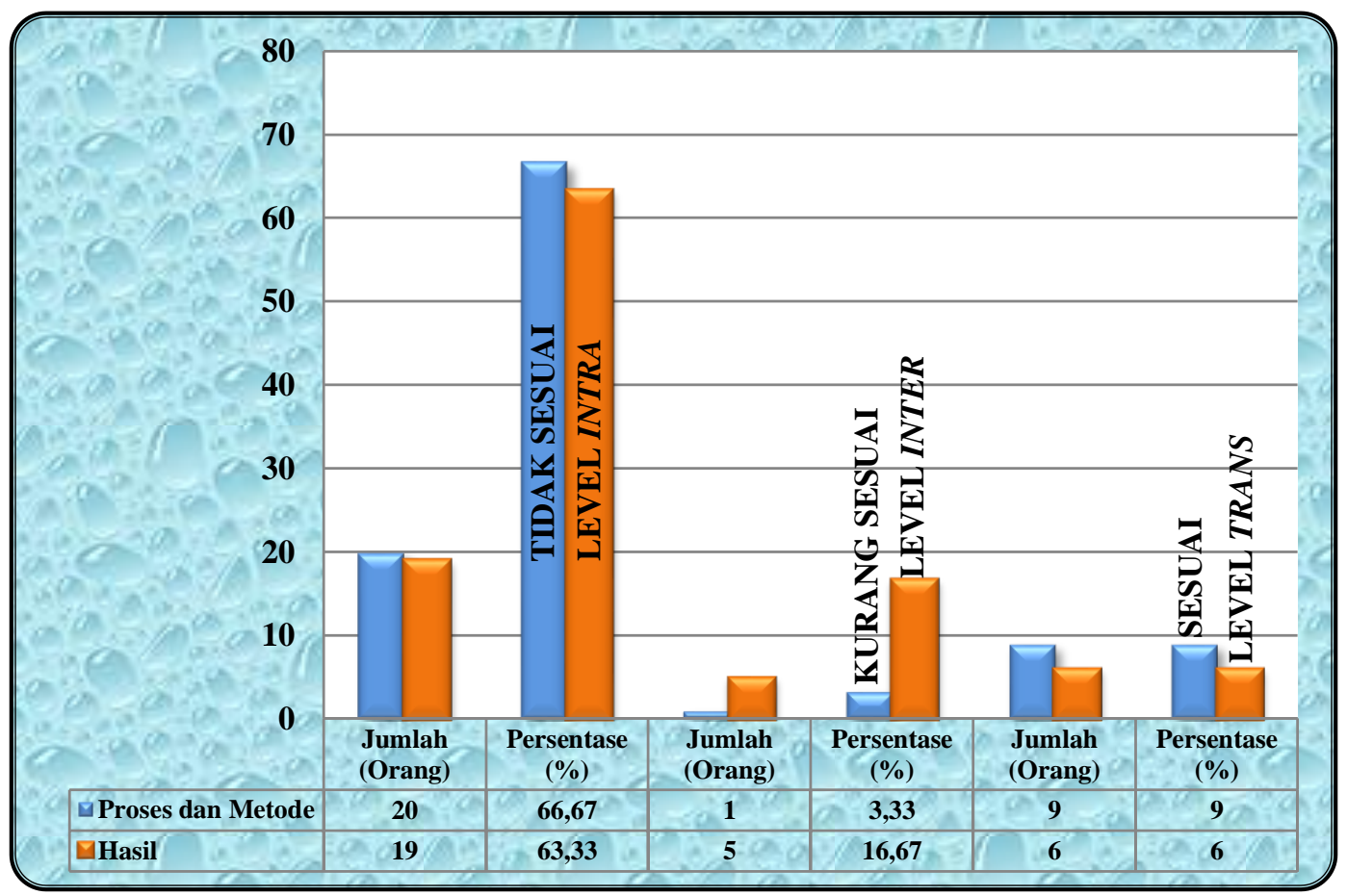

Gambar 1. Histogram Kemampuan Pemahaman Masalah Matematika Berdasarkan Dekomposisi Genetik Siswa Kelas VIII.A SMPN 2 Pondok Kelapa, Kabupaten Bengkulu Tengah

Berdasarkan konstruksi mental dalam dekomposisi genetik, hasil di atas menunjukkan bahwa konstruksi mental Aksi dengan kinerja buruk, aktivitas yang dilakukan tidak prosedural. Aktivitas dalam hal ini adalah semua tahapan yang diperlukan untuk menemukan jawaban dari setiap pertanyaan yang terdapat dalam lembar tes diagnostik. Semua tahapan harus sesuai dengan pembahasan yang diberikan. Konstruksi mental Proses menunjukkan bahwa siswa Kelas VIII.A SMPN 2 Pondok Kelapa, Kabupaten Bengkulu Tengah tidak melakukan konstruksi mental Aksi secara berulang dan refleksi terhadap jawaban dari masing-masing pertanyaan yang terdapat dalam lembar tes diagnostik.

Konstruksi mental Obyek menunjukkan bahwa siswa tidak mampu merefleksi konstruksi mental Aksi yang diterapkan untuk suatu proses tertentu dalam menjawab pertanyaan-pertanyaan yang terdapat dalam lembar tes diagnostik. Konstruksi mental Skema menunjukkan bahwa siswa tidak melaksanakan konstruksi mental Aksi, Proses dan Obyek secara baik. Hal ini merupakan implikasi dari buruknya konstruksi mental Aksi, sehingga berpengaruh terhadap buruknya konstruksi mental Proses, Obyek dan Skema. 
Secara keseluruhan, berdasarkan konstruksi mental yang membentuk Teori APOS, kondisi ini menunjukkan bahwa kemampuan pemahaman masalah matematika siswa Kelas VIII.A SMPN Pondok Kelapa, Kabupaten Bengkulu Tengah dengan kinerja buruk. Kondisi ini merupakan implikasi dari buruknya kinerja konstruksi mental Aksi, sehingga kinerja konstruksi mental lainnya, yaitu Proses, Obyek dan Skema juga dalam kondisi buruk. Artinya, keempat konstruksi mental dalam dekomposisi genetik yang ditunjukkan oleh siswa Kelas VIII.A dalam kondisi buruk.

Secara keseluruhan, berdasarkan dekomposisi genetik dengan Level Triad menunjukkan kemampuan pemahaman masalah matematika siswa Kelas VIII.A SMPN Pondok Kelapa, Kabupaten Bengkulu Tengah dengan kategori Level Intra. Siswa hanya mampu melakukan respon terhadap sifat-sifat dari obyek/peristiwa khusus secara terpisah. Artinya, siswa tidak mampu memahami secara utuh (komprehensif) pertanyaan-pertanyaan yang terdapat pada lembar tes diagnostik atau tidak mampu menginterprestasikan parameter-parameter apa saja yang tersirat dari berbagai pertanyaan yang disajikan dalam bentuk cerita dan gambar. Hal dikarenakan siswa tidak memiliki penguasaan yang baik terhadap berbagai materi prasyarat yang dibutuhkan untuk menyelesaikan masing-masing pertanyaan tersebut.

Data hasil tes diagnostik siswa Kelas VIII.B dapat dilihat pada Tabel 2.

Tabel 2. Data Hasil Tes Diagnostik Siswa Kelas VIII.B SMPN 2 Pondok Kelapa, Kabupaten Bengkulu Tengah

\begin{tabular}{|c|c|c|c|c|c|c|}
\hline \multirow{2}{*}{ No } & \multirow{2}{*}{ Inisial } & $\begin{array}{c}\text { Proses dan } \\
\text { Metode }\end{array}$ & $\begin{array}{c}\text { Jumlah } \\
\text { Jawaban } \\
\text { Benar }\end{array}$ & Skor & \multicolumn{2}{|c|}{ Kategori Kemampuan Pemahaman } \\
\cline { 5 - 7 } & & Umum & Dekomposisi Genetik \\
\hline 1 & BS & Tidak Sesuai & 2 & 25 & Kurang & Level Intra \\
\hline 2 & DJ & Tidak Sesuai & 3 & 37,5 & Kurang & Level Intra \\
\hline 3 & DK & Tidak Sesuai & 2 & 25 & Kurang & Level Intra \\
\hline 4 & DP & Sesuai & 5 & 62,5 & Cukup & Level Inter \\
\hline 5 & EN & Sesuai & 7 & 87,5 & Baik & Level Trans \\
\hline 6 & EPS & Tidak Sesuai & 4 & 50 & Kurang & Level Intra \\
\hline 7 & H & Sesuai & 6 & 75 & Baik & Level Trans \\
\hline 8 & HK & Tidak Sesuai & 4 & 50 & Kurang & Level Intra \\
\hline 9 & HN & Tidak Sesuai & 4 & 50 & Kurang & Level Intra \\
\hline 10 & IA & Sesuai & 5 & 62,5 & Cukup & Level Inter \\
\hline 11 & IM & Tidak Sesuai & 3 & 37,5 & Kurang & Level Intra \\
\hline
\end{tabular}




\begin{tabular}{|c|c|c|c|c|c|c|}
\hline \multirow{2}{*}{ No } & Inisial & $\begin{array}{c}\text { Proses dan } \\
\text { Metode }\end{array}$ & $\begin{array}{c}\text { Jumlah } \\
\text { Jawaban } \\
\text { Benar }\end{array}$ & Skor & \multicolumn{2}{|c|}{ Kategori Kemampuan Pemahaman } \\
\cline { 5 - 7 } & & Umum & Dekomposisi Genetik \\
\hline 12 & JB & Tidak Sesuai & 4 & 50 & Kurang & Level Intra \\
\hline 13 & JI & Sesuai & 6 & 75 & Baik & Level Trans \\
\hline 14 & MA & Tidak Sesuai & 4 & 50 & Kurang & Level Intra \\
\hline 15 & MD & Tidak Sesuai & 4 & 50 & Kurang & Level Intra \\
\hline 16 & NR & Sesuai & 7 & 87,5 & Baik & Level Trans \\
\hline 17 & NS & Tidak Sesuai & 4 & 50 & Kurang & Level Intra \\
\hline 18 & PS & Tidak Sesuai & 3 & 37,5 & Kurang & Level Intra \\
\hline 19 & PY & Kurang Sesuai & 5 & 62,5 & Cukup & Level Inter \\
\hline 20 & RA & Kurang Sesuai & 5 & 62,5 & Cukup & Level Inter \\
\hline 21 & RH & Tidak Sesuai & 4 & 50 & Kurang & Level Intra \\
\hline 22 & SB & Tidak Sesuai & 4 & 50 & Kurang & Level Intra \\
\hline 23 & SP & Sesuai & 6 & 75 & Baik & Level Trans \\
\hline 24 & TLS & Tidak Sesuai & 3 & 37,5 & Kurang & Level Intra \\
\hline 25 & TS & Sesuai & 6 & 75 & Baik & Level Trans \\
\hline 26 & VPA & Tidak Sesuai & 2 & 25 & Kurang & Level Intra \\
\hline 27 & YA & Tidak Sesuai & 4 & 50 & Kurang & Level Intra \\
\hline
\end{tabular}

Sumber: Data Primer, 2016

Tabel 4.2 menunjukkan kemampuan pemahaman masalah matematika ditinjau berdasarkan dekomposisi genetik pada siswa Kelas VIII.B SMPN 2 Pondok Kelapa, Kabupaten Bengkulu Tengah dengan kategori kurang (Level Intra) sebanyak 20 orang $(66,67 \%)$ yang merupakan jumlah terbanyak, kategori cukup (Level Inter) sebanyak 4 orang $(13,33 \%)$ yang merupakan jumlah paling sedikit dan kategori baik (Level Trans) sebanyak 6 orang (20\%). Namun, berdasarkan proses dan metode yang digunakan, terdapat 2 orang (50\%) dari kelompok siswa kategori cukup (Level Inter) dengan jawaban yang kurang sesuai dengan pembahasan yang diberikan.

Secara keseluruhan, kemampuan pemahaman masalah matematika siswa Kelas VIII.B di sekolah ini berdasarkan dekomposisi genetik dengan Level Triad kategori kurang (Level Intra) dengan rata-rata skor 51,67 dan rata-rata jumlah jawaban benar 4 soal (pembulatan) atau setengah (50\%) dari jumlah pertanyaan yang diberikan.

Histogram kemampuan pemahaman masalah matematika berdasarkan dekomposisi genetik siswa Kelas VIII.B dapat dilihat pada Gambar 2. 


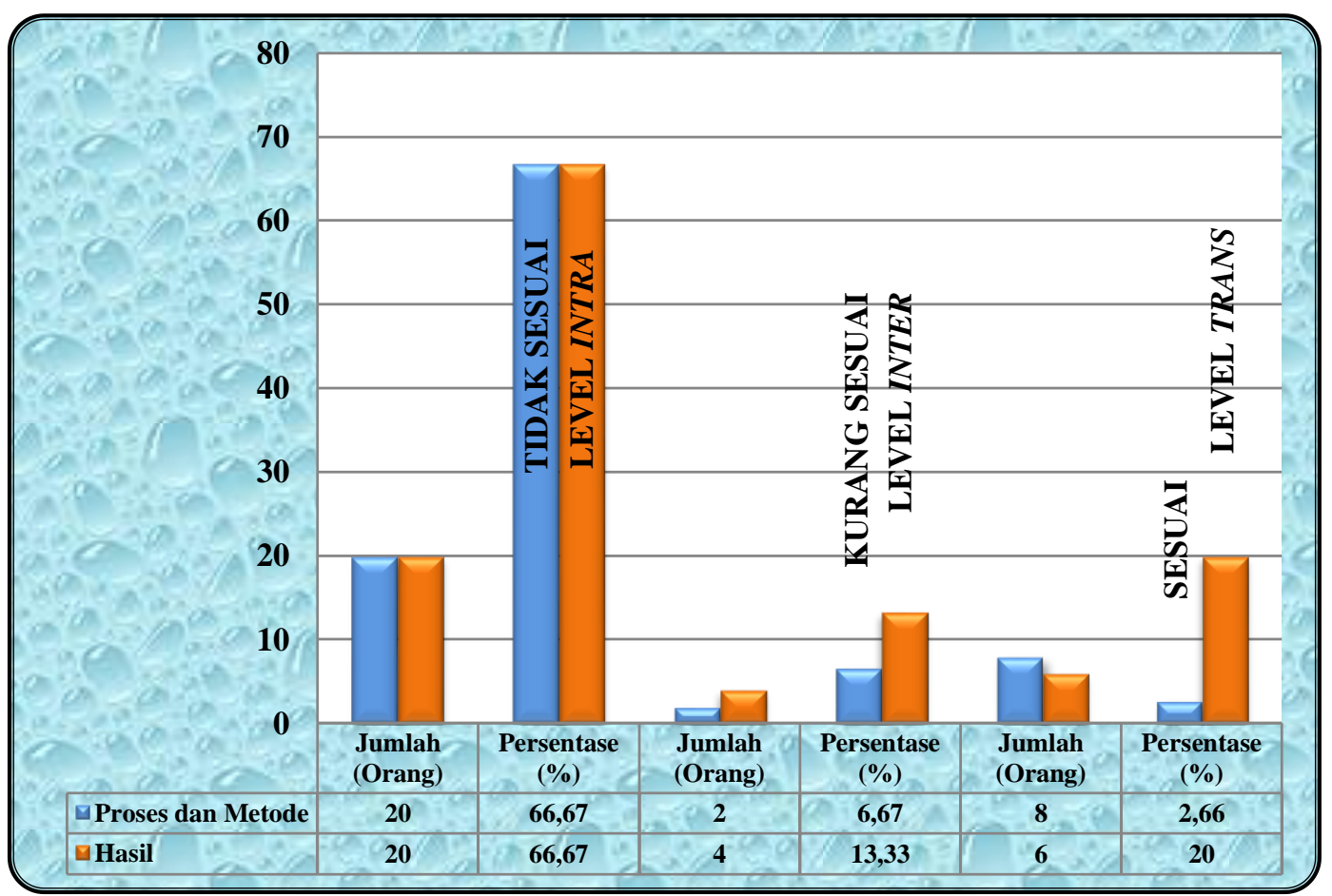

Gambar 2 Histogram Kemampuan Pemahaman Masalah Matematika Berdasarkan Dekomposisi Genetik Siswa Kelas VIII.B SMPN 2 Pondok Kelapa, Kabupaten Bengkulu Tengah

Sama halnya dengan kinerja konstruksi mental dalam dekomposisi genetik pada siswa Kelas VIII.A, jika ditinjau berdasarkan dekomposisi, hasil di atas menunjukkan bahwa konstruksi mental Aksi dengan kinerja buruk. Artinya, aktivitas atau tahapan dalam menjawab masing-masing pertanyaan yang terdapat dalam lembar tes diagnostik tidak prosedural. Aktivitas dalam hal ini adalah semua tahapan yang diperlukan untuk menemukan jawaban dari setiap pertanyaan yang terdapat dalam lembar tes diagnostik. Semua tahapan harus sesuai dengan pembahasan yang diberikan. Konstruksi mental Proses menunjukkan bahwa siswa Kelas VIII.B SMPN 2 Pondok Kelapa, Kabupaten Bengkulu Tengah tidak melakukan konstruksi mental Aksi secara berulang dan refleksi terhadap jawaban dari masing-masing pertanyaan yang terdapat dalam lembar tes diagnostik. Konstruksi mental Obyek menunjukkan bahwa siswa tidak mampu merefleksi konstruksi mental Aksi yang diterapkan untuk suatu proses tertentu dalam menjawab pertanyaan-pertanyaan yang terdapat dalam lembar tes diagnostik. Konstruksi mental Skema menunjukkan bahwa siswa tidak melaksanakan 
konstruksi mental Aksi, Proses dan Obyek secara baik. Hal ini merupakan implikasi dari buruknya konstruksi mental Aksi, sehingga berpengaruh terhadap buruknya konstruksi mental Proses, Obyek dan Skema.

Secara keseluruhan, berdasarkan konstruksi mental yang membentuk Teori APOS, kondisi ini menunjukkan bahwa kemampuan pemahaman masalah matematika siswa Kelas VIII.B SMPN Pondok Kelapa, Kabupaten Bengkulu Tengah dengan kinerja buruk. Hal ini merupakan implikasi dari buruknya kinerja konstruksi mental Aksi, sehingga kinerja konstruksi mental lainnya, yaitu Proses, Obyek dan Skema juga dalam kondisi buruk. Artinya, keempat konstruksi mental dalam dekomposisi genetik yang ditunjukkan oleh siswa Kelas VIII.B dalam kondisi buruk.

Secara keseluruhan, berdasarkan dekomposisi genetik dengan Level Triad menunjukkan kemampuan pemahaman masalah matematika siswa Kelas VIII.A SMPN Pondok Kelapa, Kabupaten Bengkulu Tengah dengan kategori Level Intra. Siswa hanya mampu melakukan respon terhadap sifat-sifat dari obyek/peristiwa khusus secara terpisah. Artinya, siswa tidak mampu memahami secara utuh (komprehensif) pertanyaan-pertanyaan yang terdapat pada lembar tes diagnostik atau tidak mampu menginterprestasikan parameter-parameter apa saja yang tersirat dari berbagai pertanyaan yang disajikan dalam bentuk cerita dan gambar. Hal dikarenakan siswa tidak memiliki penguasaan yang baik terhadap berbagai materi prasyarat yang dibutuhkan untuk menyelesaikan masing-masing pertanyaan tersebut.

Tabel 3. Rekapitulasi Data Hasil Tes Diagnostik Siswa Kelas VIII

SMPN 2 Pondok Kelapa, Kabupaten Bengkulu Tengah

\begin{tabular}{|c|c|c|c|c|}
\hline $\begin{array}{c}\text { Jumlah Jawaban } \\
\text { Benar }\end{array}$ & Skor & \multirow{2}{*}{ Jumlah Responden } & \multicolumn{2}{|c|}{ Kategori Kemampuan Pemahaman } \\
\cline { 3 - 5 } & & Secara Umum & Dekomposisi Genetik \\
\hline \hline 1 & 12,5 & 0 & Kurang & Level Intra \\
\hline 2 & 25 & 8 & Kurang & Level Intra \\
\hline 3 & 37,5 & 13 & Kurang & Level Intra \\
\hline 4 & 50 & 18 & Kurang & Level Intra \\
\hline 5 & 62,5 & 9 & Cukup & Level Inter \\
\hline 6 & 75 & 8 & Baik & Level Trans \\
\hline 7 & 87,5 & 3 & Baik & Level Trans \\
\hline 8 & 100 & 1 & Baik & Level Trans \\
\hline \hline \multicolumn{6}{r}{} & Total & $\mathbf{6 0}$ & Kurang & Level Intra \\
\hline
\end{tabular}

Sumber: Data Primer, 2016 
Tabel 4.3 menunjukkan bahwa dari rekapitulasi data hasil tes diagnostik siswa Kelas VIII SMPN 2 Pondok Kelapa, Kabupaten Bengkulu Tengah diketahui kemampuan pemahaman masalah matematika berdasarkan dekomposisi genetik termasuk kategori kurang (Level Intra) sebanyak 39 orang (65\%) yang merupakan jumlah terbanyak, kategori cukup (Level Inter) sebanyak 9 orang $(15 \%)$ yang merupakan jumlah paling sedikit dan kategori baik (Level Trans) sebanyak 12 orang $(20 \%)$. Secara keseluruhan, kemampuan pemahaman masalah matematika berdasarkan dekomposisi genetik siswa Kelas VIII di sekolah ini termasuk kategori kurang (Level Intra).

Secara keseluruhan, histogram kemampuan pemahaman masalah matematika berdasarkan dekomposisi genetik siswa Kelas VIII SMPN 2 Pondok Kelapa, Kabupaten Bengkulu Tengah dapat dilihat pada Gambar 3.

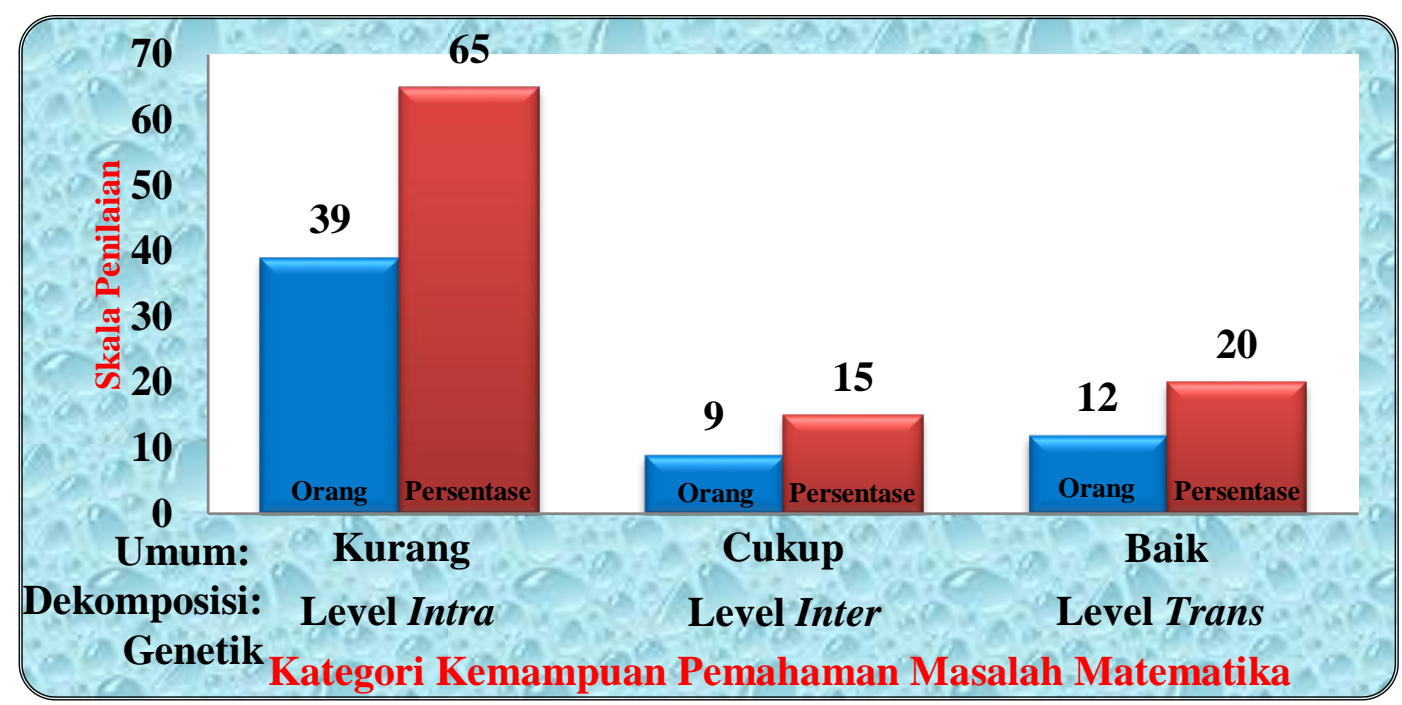

Gambar 3. Histogram Kemampuan Pemahaman Masalah Matematika Berdasarkan Dekomposisi Genetik Siswa Kelas VIII SMPN 2 Pondok Kelapa, Kabupaten Bengkulu Tengah

Secara keseluruhan, berdasarkan konstruksi mental yang membentuk Teori APOS, kondisi ini menunjukkan bahwa kemampuan pemahaman masalah matematika berdasarkan dekomposisi genetik pada siswa Kelas VIII SMPN Pondok Kelapa, Kabupaten Bengkulu Tengah dengan kinerja buruk. Hal ini merupakan implikasi dari buruknya kinerja konstruksi mental Aksi, sehingga kinerja konstruksi mental lainnya, yaitu Proses, Obyek dan Skema juga dalam kondisi buruk. Artinya, 
untuk mampu menghasilkan kinerja yang baik, maka hal utama harus diperhatikan oleh siswa adalah bagaimana mereka dapat menunjukkan kinerja yang baik pada konstruksi mental Aksi sebagai konstruksi mental basis (dasar) dalam dekomposisi genetik. Baik dan buruknya konstruksi mental Aksi sangat dipengaruhi oleh pemahaman siswa terhadap materi prasyarat yang harus dikuasai untuk mampu memahami materi dan soal yang berhubungan dengan Sistem Persamaan Linier Dua Variabel (SPLDV).

Secara keseluruhan, berdasarkan dekomposisi genetik dengan Level Triad menunjukkan kemampuan pemahaman masalah matematika siswa Kelas VIII SMPN Pondok Kelapa, Kabupaten Bengkulu Tengah dengan kategori Level Intra. Siswa hanya mampu melakukan respon terhadap sifat-sifat dari obyek/peristiwa khusus secara terpisah. Artinya, siswa tidak mampu memahami secara utuh (komprehensif) pertanyaan-pertanyaan yang terdapat pada lembar tes diagnostik atau tidak mampu menginterprestasikan parameter-parameter apa saja yang tersirat dari berbagai pertanyaan yang disajikan dalam bentuk cerita dan gambar. Hal dikarenakan siswa tidak memiliki penguasaan yang baik terhadap berbagai materi prasyarat yang dibutuhkan untuk menyelesaikan masing-masing pertanyaan tersebut.

\section{Peta Kemampuan Pemecahan Masalah Matematika Berdasarkan Dekomposisi Genetik pada Siswa Kelas VIII SMPN 2 Pondok Kelapa Kabupaten Bengkulu Tengah}

Berdasarkan hasil tes diagnostik terbentuk 5 (lima) kelompok. Pembentukan kelima kelompok tersebut didasarkan atas kesamaan proses dan metode yang digunakan dalam menjawab pertanyaan-pertanyaan yang terdapat dalam lembar tes diagnostik. Oleh karena itu, data hasil wawancara terstruktur diperoleh dengan melakukan wawancara terhadap 1 (satu) orang perwakilan dari masing-masing kelompok tersebut.

Berdasarkan hasil wawancara terstruktur menunjukkan bahwa peta kemampuan pemahaman masalah matematika berdasarkan dekomposisi genetik pada siswa Kelas VIII SMPN Pondok Kelapa, Kabupaten Bengkulu hanya siswa perwakilan dari Kelompok I yang memahami secara detil mengenai materi 
prasyarat yang dibutuhkan, langkah-langkah penyelesaian dan kendala yang dihadapi dalam mengerjakan setiap soal yang terdapat dalam lembar tes diagnostik. Hal ini karena anggota dari Kelompok I merupakan siswa dengan kemampuan pemahaman masalah matematika tergolong baik (Level Trans), baik dari aspek proses dan metode yang digunakan maupun aspek hasil (jumlah jawaban benar).

Siswa perwakilan Kelompok II mampu menjelaskan setiap pertanyaan yang terdapat pada panduan wawancara, namun tidak sedetil penjelasan yang diberikan oleh siswa perwakilan Kelompok I. Hal ini karena anggota Kelompok II merupakan siswa dengan kemampuan pemahaman masalah matematika tergolong cukup (Level Intra), baik dari aspek proses dan metode yang digunakan maupun aspek hasil (jumlah jawaban benar).

Siswa perwakilan Kelompok III, IV dan V tidak mampu memberikan jawaban secara detil terhadap seluruh pertanyaan yang terdapat pada panduan wawancara. Masing-masing perwakilan dari ketiga kelompok ini hanya mampu memberikan jawaban singkat tanpa mampu memberikan penjelasan tambahan mengenai jawaban yang diberikannya. Hal ini karena anggota dari ketiga kelompok merupakan siswa dengan kemampuan pemahaman masalah matematika tergolong kurang ((Level Intra), baik dari aspek proses dan metode yang digunakan maupun aspek hasil (jumlah jawaban benar).

Secara keseluruhan, berdasarkan data hasil tes diagnostik dan data hasil wawancara terstruktur yang dilakukan terhadap 60 siswa Kelas VIII SMPN Pondok Kelapa, Kabupaten Bengkulu Tengah dapat disimpulkan bahwa hanya 2 kelompok (tiap kelompok terdiri atas 12 siswa) dengan kemampuan pemahaman masalah matematika ditinjau berdasarkan dekomposisi genetik dengan Level Triad tergolong baik (Level Trans) dan cukup (Level Inter) atau dengan kata lain memadai untuk mampu mengerjakan masalah-masalah matematika, khususnya yang berkenaan dengan pokok bahasan Sistem Persamaan Linier Dua Variabel (SPLDV). Artinya, sebanyak 24 siswa (40\%) dengan kemampuan pemahaman masalah matematika tergolong baik (Level Trans) dan cukup (Level Inter) serta 36 siswa (60\%) tergolong kurang (Level Intra). 
Diskusi mengenai gambaran kemampuan pemecahan masalah matematika dan peta kemampuan tersebut ditinjau berdasarkan dekomposisi genetik pada siswa Kelas VIII SMPN 2 Pondok Kelapa, Kabupaten Bengkulu Tengah diuraikan sebagai berikut:

\section{Kemampuan Pemecahan Masalah Matematika Berdasarkan Dekomposisi Genetik pada Siswa Kelas VIII SMPN 2 Pondok Kelapa, Kabupaten \\ Bengkulu Tengah}

Berdasarkan data hasil tes diagnostik yang terdiri atas 8 (delapan) masalah matematika yang disajikan dalam bentuk cerita dan gambar menunjukkan bahwa kemampuan pemecahan masalah matematika ditinjau berdasarkan dekomposisi genetik pada siswa Kelas VIII SMPN 2 Pondok Kelapa Kabupaten Bengkulu Tengah termasuk kategori kurang (Level Intra) berdasarkan 2 (dua) aspek penilaian, yaitu proses dan metode yang digunakan serta hasil (jumlah jawaban benar).

Berdasarkan aspek proses dan metode yang digunakan, kemampuan pemecahan masalah matematika siswa Kelas VIII SMPN 2 Pondok Kelapa Kabupaten Bengkulu Tengah yang termasuk kategori baik (Level Trans) sebanyak 17 orang $(28,33 \%)$. Artinya, jawaban yang diberikan oleh ketujuh belas siswa tersebut sesuai dengan pembahasan yang diberikan. Siswa yang termasuk kategori kemampuan cukup (Level Inter) sebanyak 4 orang (6,67\%). Artinya, jawaban yang diberikan oleh responden pada kategori ini kurang sesuai dengan pembahasan yang diberikan. Siswa yang termasuk kategori kemampuan kurang (Level Intra) sebanyak 39 orang (65\%). Artinya, jawaban yang diberikan oleh responden pada kategori ini tidak sesuai dengan pembahasan yang diberikan.

Siswa dengan kategori kemampuan pemecahan masalah matematika tergolong baik (Level Trans), mampu mencapai sifat-sifat global baru yang tidak dapat diakses pada level-level yang lain (intra dan inter) (Wahyu, 2005: 53). Artinya, siswa mampu menerapkan secara tepat dan benar semua konsep (materi) prasyarat tersebut di atas untuk menjawab pertanyaan-pertanyaan yang terdapat dalam tes diagnostik.

Siswa dengan kategori kemampuan pemecahan masalah matematika tergolong cukup (Level Inter), mampu memahami hubungan-hubungan yang terjadi 
pada suatu obyek/peritiwa dan dapat menyimpulkan berdasarkan suatu operasi awal dengan beberapa pemahaman dan operasi lain sebagai akibatnya atau hanya dapat mengkoordinasikan dengan operasi-operasi yang sama (Wahyu, 2005: 53). Artinya, siswa terkadang kebingungan dalam menggunakan materi prasyarat mana yang paling tepat untuk menjawab pertanyaan-pertanyaan yang terdapat dalam tes diagnostik.

Siswa dengan kategori kemampuan pemecahan masalah matematika tergolong kurang (Level Intra), hanya mampu melakukan respon terhadap sifatsifat dari obyek/peristiwa khusus secara terpisah (Wahyu, 2005: 53). Artinya, siswa tidak mampu menerapkan secara tepat dan benar semua konsep (materi) prasyarat tersebut di atas untuk menjawab pertanyaan-pertanyaan yang terdapat dalam tes diagnostik. Hal ini dikarenakan siswa tidak mampu memahami secara utuh (komprehensif) pertanyaan-pertanyaan yang terdapat pada lembar tes diagnostik atau tidak mampu menginterprestasikan parameter-parameter apa saja yang tersirat dari berbagai pertanyaan yang disajikan dalam bentuk cerita dan gambar. Hal dikarenakan siswa tidak memiliki penguasaan yang baik terhadap berbagai materi prasyarat yang dibutuhkan untuk menyelesaikan masing-masing pertanyaan tersebut.

Secara umum dapat diketahui bahwa penilaian terhadap kemampuan pemecahan masalah matematika sangat penting diketahui oleh guru mata pelajaran untuk dijadikan sebagai bahan evaluasi dan perbaikan dalam memberikan materi kepada siswa. Guru berupaya untuk mengupayakan agar setiap materi yang diajarkan kepada siswa dapat dikuasai dengan baik oleh mereka. Penguasaan materi pelajaran yang baik untuk setiap Standar Kompetensi (SK) yang diuraikan lagi dalam berbagai Kompetensi Dasar (KD) akan mampu meningkatkan kemampuan pemecahan masalah matematika siswa untuk materi apapun yang diujikan.

Berdasarkan aspek hasil (jumlah jawaban benar), kemampuan pemecahan masalah matematika siswa Kelas VIII SMPN 2 Pondok Kelapa Kabupaten Bengkulu Tengah yang termasuk kategori baik (Level Trans) sebanyak 12 orang (20\%). Artinya, seluruh siswa pada kategori ini mampu menjawab dengan benar pertanyaan yang terdapat dalam tes diagnostik minimal sebanyak 6 soal dengan 
skor 75. Siswa yang termasuk kategori kemampuan cukup (Level Inter) sebanyak 9 orang (15\%). Artinya, seluruh siswa pada kategori ini mampu menjawab dengan benar pertanyaan yang terdapat dalam tes diagnostik sebanyak 5 soal dengan skor 62,5. Siswa yang termasuk kategori kemampuan kurang (Level Intra) sebanyak 39 orang (65\%). Artinya, seluruh siswa pada kategori ini mampu menjawab dengan benar pertanyaan yang terdapat dalam tes diagnostik maksimal sebanyak 4 soal dengan skor 50.

Aspek hasil merupakan hasil dari aspek proses dan metode yang digunakan. Aspek proses dan metode yang digunakan merupakan hasil dari pengetahuan dan keterampilan matematika yang dimiliki siswa. Artinya, jika pengetahuan dan keterampilan matematika siswa tergolong kurang, maka aspek proses dan metode yang digunakan juga akan tergolong kurang. Implikasinya, aspek hasil juga akan tergolong kurang. Sebaliknya, pengetahuan dan keterampilan matematika siswa tergolong baik akan menghasilkan aspek proses dan metode yang digunakan serta aspek hasil yang baik juga.

Kemampuan pemecahan matematika siswa Kelas VIII SMPN 2 Pondok Kelapa, Kabupaten Bengkulu Tengah ditinjau berdasarkan dekomposisi genetik yang diaplikasikan dalam Teori Action, Process, Object and Scheme (APOS) atau Teori Aksi, Proses, Obyek dan Skema sebagai konstruksi mental yang membentuk dekomposisi genetik. Keempat konstruksi mental tersebut diuraikan sebagai berikut:

1. Aksi

Berdasarkan konstruksi mental Aksi (Action), kemampuan pemecahan masalah matematika siswa Kelas VIII pada sekolah ini menunjukkan bahwa kinerja yang buruk, yaitu aktivitas yang dilakukan tidak prosedural. Siswa tidak mampu memberikan jawaban yang sistematis, berurutan dan terarah dalam menjawab pertanyaan-pertanyaan yang terdapat dalam tes diagnostik.

Faktor dominan penyebab buruknya kinerja siswa dalam konstruksi mental Aksi adalah siswa tidak memiliki pengetahuan dan keterampilan matematika yang cukup, yaitu lima materi prasyarat yang dibutuhkan untuk mampu memahami berbagai masalah matematika yang berhubungan dengan materi SPLDV yang telah 
disampaikan oleh guru mata pelajaran matematika di Kelas VII (semester I dan II) serta Kelas VIII (semester I).

\section{Proses}

Berdasarkan konstruksi mental Proses (Process), kemampuan pemecahan masalah matematika siswa Kelas VIII pada sekolah ini menunjukkan bahwa siswa tidak melakukan konstruksi mental Aksi secara berulang dan refleksi terhadap jawaban dari pertanyaan-pertanyaan yang terdapat dalam tes diagnostik. Artinya, setelah menjawab pertanyaan-pertanyaan tersebut, siswa tidak melakukan pemeriksaan kembali (recheck) untuk memastikan kebenaran dari jawaban yang diberikan.

Faktor dominan penyebab buruknya kinerja konstruksi mental Proses ini adalah buruknya kinerja konstruksi mental Aksi siswa tersebut. Hal ini menunjukkan bahwa jika kinerjakonstruksi mental Aksi buruk, maka kinerja konstruksi mental Proses juga akan buruk. Oleh karena itu, siswa harus memahami sepenuhnya semua materi prasyarat yang berhubungan dengan materi SPLDV.

3. Obyek

Berdasarkan konstruksi mental Obyek (Object), kemampuan pemecahan masalah matematika siswa Kelas VIII pada sekolah ini menunjukkan bahwa siswa tidak mampu merefleksi aksi yang diterapkan untuk suatu proses tertentu dalam menjawab pertanyaan-pertanyaan yang terdapat dalam lembar tes diagnostik. Refleksi akan mampu dilakukan siswa jika siswa memahami sepenuhnya apa yang diketahui dan apa yang ditanya dari soal serta materi apa yang dibutuhkan untuk mampu menjawab dengan tepat dan benar dari setiap pertanyaan yang ada.

Faktor dominan penyebab buruknya gambaran konstruksi mental Obyek ini adalah buruknya kinerja konstruksi mental Aksi dan Proses para siswa. Hal ini menunjukkan bahwa jika kinerja konstruksi mental Aksi dan Proses buruk, maka kinerja konstruksi mental Obyek juga akan buruk atau sebaliknya. Oleh karena itu, siswa harus memahami sepenuhnya semua materi prasyarat yang berhubungan dengan materi SPLDV. 
4. Skema

Konstruksi mental Skema merupakan tingkatan konstruksi mental tertinggi dalam Teori APOS, karena konstruksi mental ini merupakan gabungan dari konstruksi mental Aksi, Proses dan Obyek yang diaplikasi dalam memecahkan permasalahan dalam matematika. Kinerja konstruksi mental Skema siswa akan baik jika kinerja konstruksi mental Aksi, Proses dan Obyeknya juga baik. Sebaliknya, kinerja konstruksi mental Skema siswa akan buruk jika kinerja konstruksi mental Aksi, Proses dan Obyeknya dalam keadaan buruk juga.

Faktor dominan penyebab buruknya kinerja konstruksi mental Skema ini adalah buruknya kinerja konstruksi mental Aksi, Proses dan Obyek para siswa. Untuk dapat memperbaiki kinerja konstruksi mental Skema, maka cara utama yang dapat dilakukan siswa dengan memahami sepenuhnya materi prasyarat untuk mampu menguasai materi yang berhubungan dengan SPLDV.

\section{Peta Kemampuan Pemecahan Masalah Matematika Berdasarkan Dekomposisi Genetik pada Siswa Kelas VIII SMPN 2 Pondok Kelapa, Kabupaten Bengkulu Tengah}

Berdasarkan data hasil tes diagnostik dan data hasil wawancara terstruktur menunjukkan bahwa peta kemampuan pemecahan masalah matematika ditinjau berdasarkan dekomposisi genetik dengan Level Triad pada siswa Kelas VIII SMPN 2 Pondok Kelapa, Kabupaten Bengkulu Tengah sebanyak 24 siswa (40\%) dengan kemampuan pemahaman masalah matematika tergolong baik dan cukup (memadai). Artinya, kinerja keempat konstruksi mental pada dekomposisi genetik yang meliputi Aksi, Proses, Obyek dan Skema dengan kinerja baik serta 36 siswa (60\%) tergolong kurang (tidak memadai) yang artinya, kinerja keempat konstruksi mental pada dekomposisi genetik yang meliputi Aksi, Proses, Obyek dan Skema dengan kinerja buruk.

Penyebab dominan buruknya kinerja keempat konstruksi mental tersebut di atas, khususnya pada siswa yang berjumlah 36 orang (60\%), karena buruknya kinerja konstruksi mental Aksi, yaitu aktivitas atau semua tahapan dalam menjawab masing-masing pertanyaan yang terdapat dalam lembar tes diagnostik tidak 
prosedural. Implikasinya, kinerja konstruksi mental lainnya yang meliputi Proses, Obyek dan Skema juga menjadi buruk.

\section{SIMPULAN}

Berdasarkan hasil penelitian dan diskusi mengenai kemampuan pemecahan masalah matematika ditinjau berdasarkan dekomposisi genetik pada siswa Kelas VIII SMPN 2 Pondok Kelapa, Kabupaten Bengkulu Tengah, maka simpulan yang dapat diambil sebagai berikut:

a. Kemampuan pemecahan masalah matematika berdasarkan dekomposisi genetik pada siswa Kelas VIII SMPN 2 Pondok Kelapa Kabupaten Bengkulu Tengah menunjukkan bahwa termasuk kategori kurang (Level Intra) sebanyak 39 orang (65\%) yang merupakan jumlah terbanyak, kategori cukup (Level Inter) sebanyak 9 orang (15\%) yang merupakan jumlah paling sedikit dan kategori baik (Level Trans) sebanyak 12 orang (20\%). Secara keseluruhan, kemampuan pemahaman masalah matematika berdasarkan dekomposisi genetik siswa Kelas VIII di sekolah tersebut termasuk kategori kurang (Level Intra).

b. Peta kemampuan pemecahan masalah matematika berdasarkan dekomposisi genetik pada siswa Kelas VIII SMPN 2 Pondok Kelapa Kabupaten Bengkulu Tengah menunjukkan bahwa sebanyak 24 siswa (40\%) dengan kinerja konstruksi mental Aksi, Proses, Skema dan Obyek yang baik dan 36 siswa (60\%) dengan kinerja konstruksi mental Aksi, Proses, Skema dan Obyek yang buruk. Faktor penyebab buruk kinerja siswa ini adalah buruknya kinerja konstruksi mental Aksi, dimana siswa aktivitas ataupun tahapan dalam menjawab semua pertanyaan yang terdapat dalam lembar tes diagnosti tidak prosedural. Implikasinya, kinerja tiga konstruksi mental lainnya ikut menjadi buruk. Namun penyebab utama buruk kinerja siswa berdasarkan dekomposisi genetik, karena siswa tidak memahami dan menguasai materi prasyarat yang dibutuhkan untuk mampu memahami materi dan mengerjakan pertanyaan-pertanyaan yang berhubungan dengan pokok bahasan Sistem Persamaan Linier Dua Variabel (SPLDV). 


\section{DAFTAR PUSTAKA}

Asiala, M., Cotrill, J., Dubinsky, E., \& Schwigendorf, K.E. 2004. The Development of Student's Graphical Understanding of the Derivative. Journal of Matehematical Behaviour. Vol. 16, No. 4: 399-341.

Basyaib, F. 2006. Teori Pembuat Keputusan. Jakarta: Grasindo.

Djamarah, S.B \& Zain, A. 2002. Strategi Belajar Mengajar. Cetakan Ke- 2. Jakarta: Rineka Cipta.

Dubinsky, E.D \& McDonald, M.A. 2001. APOS: A Contructivist Theory of Learning in Undergraduate Mathematics Education Research: Research in Collegiate Mathematics Education II, CBMS Issues in Mathematics Education.

Ghani, G. 2003. Pembelajaran Matematika. Jakarta: Rineka Cipta.

Haji, S. 2008. Meningkatkan Kemampuan Pemecahan Masalah melalui Pendekatan Matetik Realistik di SMPN 1 Kotamadya Bengkulu. Jurnal Didaktik. Universitas Mulawarman, Samarinda. Vol.7, No.4. September 2008.

Haji, S. 2009. Pengaruh Pembelajaran Berbasis Masalah terhadap Kemampuan Pemecahan Masalah di SMP Kota Bengkulu. Seminar Nasional dan Rapat Tahunan Bidang MIPA. Universitas Syiah Kuala, Banda Aceh. 4-5 Mei 2009.

Herman Hudojo. 2009. Pengembangan Kurikulum dan Pembelajaran Matematika. Malang: Universitas Negeri Malang Press.

Mahmudah, S. 2014. Analisis Tingkat Pemahaman Peserta Didik pada Materi Besaran dan Satuan Menggunakan Teori APOS (Studi Kasus Kelas X MA Tajul Ulum Brabo Grobogan Tahun Pelajaran 2014/2015). Jurusan Pendidikan Ilmu Fisika, Fakultas Ilmu Tarbiyah dan Keguruan, Institut Agama Islam Walisongo, Semarang (Skripsi tidak Dipublikasikan).

Mulyono, A. 2009. Pendidikan bagi Anak yang Berkesulitan Belajar. Jakarta: Rineka Cipta.

Nurdin, L. 2012. Analisis Pemahaman Siswa tentang Barisan Berdasarkan Teori APOS (Action, Process, Object and Scheme). [Artikel].

Nurhadi. 2004. Kurikulum 2004: Pertanyaan dan Jawaban. Jakarta: Grasindo.

Nurlaelah, E. 2005. Inovasi Pembelajaran Struktur Alajabar I dengan Menggunakan

Program ISETL Berdasarkan Teori APOS. Jurnal Pengajaran MIPA. Vol. 6, No. 1, Juni 2005. ISSN: 1412-0917: 1-8.

Risnawati. 2008. Strategi Pembelajaran Matematika. Pekanbaru: UIN Suska Press.

Shadiq, F. 2005. Pemecahan Masalah dalam Pembelajaran Matematika. Yogyakarta: Pusat Pengembangan dan Penataran Guru Matematika.

Slameto. 2010. Belajar dan Faktor-faktor yang Mempengaruhinya. Jakarta: Rineka Cipta.

Sudrajat, A. 2009. Teori-teori Belajar. Jakarta: Penerbit Erlangga.

Sugiyono. 2013. Metodologi Penelitian Kuantitatif, Kualitatif, dan $R \& D$. Bandung: Alfabeta.

Suharsimi, A. 2006. Prosedur Penelitian: Suatu Pendekatan Praktik. Jakarta: Rineka Cipta.

Suherman, H. 2009. Strategi Pembelajaran Matematika Kontemporer. Bandung:

JICA, Universitas Pendidikan Indonesia. 
Wardhani, I.G.A.K. 2005. Dasar-dasar Komunikasi dan Keterampilan Dasar Mengajar. Jakarta: Universitas Terbuka Press.

Warsita, W.D. 2009. Proses Berpikir Kreatif Siswa dalam Memecahkan Masalah Open-Ended. [Jurnal] Jurusan Pendidikan Matematika, Fakultas Ilmu Keguruan dan Ilmu Pendidikan, Universitas Negeri Surabaya.

Wena, M. 2010. Strategi Pembelajaran Inovatif Kontemporer. Jakarta: Bumi Aksara.

Wahyu Widada. 2005. Dekomposisi Genetik: Teori APOS pada Pembelajaran Kalkulus. Inspirasi: Jurnal Ilmiah Multiscience. Universitas Muhammadiyah Bengkulu. Vol. 20, No. 1. ISSN 0854-4808: 1-65.

Wahyu Widada. 2015. The Existence of Students in Trans Extended Cognitive Development on Learning of Graph Theory. Jurnal Math Educator Nusantara. Vol. 1, No. 1, Mei 2015. ISSN: 2459-97345: 1-20. 